\title{
POST-ELECTION SITUATION IN UKRAINE: CHANGING FACES OR IDEOLOGICAL TRANSFORMATIONS?
}

\section{Kroytor A. V., Yakovlev D. V.}

...ideology never says, "I am ideological" It is necessary to be outside ideology, i.e. in scientific knowledge, to be able to say: I am in ideology (a quite exceptional case) or (general case): I was in ideology.

As is well known, the accusation of being in ideology only applies to others, never to oneself (unless one is really a Spinozist or a Marxist ...) Althusser, Louis (1971).

Ideology and Ideological State Apparatuses. Notes toward an investigation.

In L. Althusser, Lenin and philosophy and other essays. Ben Brewster, Trans. New York: Monthly Review Press. p. 49.

\section{INTRODUCTION}

There is a gradual construction of a new ideological design in Ukraine. After the collapse of the Soviet Union, the devastating consequences of a one-party political system became apparent to all. For the newly formed political actors, the "golden times" came. It seemed that it was possible to move on from the discussions of the perestroika to the clash of ideologies in national states: "Since the collapse of the Soviet Union in 1991, the inhabitants of its former republics have witnessed the return of history in their homelands. The Soviet illusion of a preordained and predestined future has been replaced by a sense of unpredictability about the future coupled with a sense of vulnerability vis-à-vis history in these new states... Formerly engaged in the dogmas of Soviet Marxism, ideological creativity has returned to the new societies that are currently dwelling on the ruins of the USSR. History 
has repatriated the post-Soviet lands as a conflict of ideas and a clash of ideologies" (Minakov, 2012) ${ }^{1}$.

Were political parties able to take advantage of this and, in cooperation with civil society, come up with ideological identification and formulate their ideological doctrines? During the existence of the Ukrainian party system, it has become competitive and pluralistic, but it is mostly the competition not of ideologies but leaders and technologies $\left(\right.$ Barkouski, 2018) ${ }^{2}$. There are ideologies, but a mass voter does not vote by ideological criteria. The 2019 parliamentary elections are another confirmation of this.

The "marks" of ideological forms and transformations are defined and studied in various social spaces and social interactions of the postSoviet countries. In particular, these are the studies of ideological innovations in party politics (Minakov, 2012 ${ }^{3}$; Mochulska, 2017 ; Whitmore, $2014^{5}$ ), public policy and youth policy (Barrett R., 2018 Yenin, $2018^{7}$ ), education and science (Guttke, Küchler, \& Shvaika 2012 ${ }^{8}$;

${ }^{1}$ Minakov, M. (2012). Ideological Innovations in the Post-Soviet Countries. Editorial introduction. The Ideology and Politics Journal, № 1, pp. 2-4. Retrieved from https://ideopol.org/wp-content/uploads/2014/03/1_ENG__Minakov.pdf

${ }^{2}$ Barkouski, P. (2018). Contemporary post-ideologies: "hybrid ideologies", or "new mythologies" as a factor of constituting of post-modern social field, The Ideology and Politics Journal, № 3(11), pp. 13-55. Retrieved from https://ideopol.org/wp-content/uploads/2018/ $12 /$ Eng_2018\%203.\%204.\%20Barkouski\%20.pdf

${ }^{3}$ Minakov, M. (2012). Ideological Innovations in the Post-Soviet Countries. Editorial introduction. The Ideology and Politics Journal, № 1, pp. 2-4. Retrieved from https://ideopol.org/wp-content/uploads/2014/03/1_ENG__Minakov.pdf

${ }^{4}$ Mochulska, M. (2017).The legal status of political parties in Ukraine: peculiarities and improvement. Zeszyty naukowe, № 4. Retrieved from http://iusetadministratio.eu/wpcontent/Zeszyty_naukowe/2017/4_2017/4_2017_1_Mochulska.pdf

${ }^{5}$ Whitmore, S. (2014). Political party development in Ukraine. GSDRC Helpdesk Research, Birmingham, UK, 2014, Report 1146, pp. 1-13. Retrieved from http://www.gsdrc.org/ docs/open/hdq1146.pdf

${ }^{6}$ Barrett, R. (2018). Ukraine at the Crossroad in Post-Communist Europe : Policymaking and the Role of Foreign Actors. Dissertations, 259 p. Retrieved from https://irl.umsl.edu/dissertation/725

7 Yenin, M. (2018). Ideological forms and value modifications of patriotism of Ukrainian youth (based on analysis of moderated group discussions), The Ideology and Politics Journa, № 2(10). Retrieved from https://ideopol.org/wp-content/uploads/2019/01/ 2 . $\% 203 . \% 202018 . \% 20$ ENG.\%20Yenin.pdf 
Yakovlev \& Kreutor, 2018 ${ }^{9}$; Kroytor, Yakovlev \& AleksentsevaTimchenko, $2019^{10}$ ), public engagement and political participation (Cianciara \& Zacharuk, 2018 ${ }^{11}$ ), history and politics of memory (Umland, Yurchuk \& Fedor, 2018 ${ }^{12}$ ).

Nowadays the Ukrainian party system is at a crossroads. On the one hand, there are the old parties ("Seasoned Wolfs") that have gone the complicated way and gradually formed their ideological doctrines and identifications in the fight against right-wing radicals, communists, and had a close relationship with various "parties of power" (Yakovlev, $2015)^{13}$. On the other hand, there are young, ambitious parties who are also leaders' projects. However, marketing and targeting are more trusted than good old ideologies. According to the results of the 2019 parliamentary elections, the first to be mentioned is Fatherland, Opposition Platform - For Life, and European Solidarity. The others who have just started to search for their ideological niche are Servant of the People and Voice.

${ }^{8}$ Guttke, M., Küchler, F., Shvaika, O. (2012). Ideological Foundations of Educational Reforms in Ukraine, The Ideology and Politics Journa, № 2,.pp.4-13. Retrieved from https://ideopol.org/wp-content/uploads/2014/03/2_ENG-ED-Kuechler.pdf

${ }^{9}$ Yakovlev, D., Kreutor, A.. (2018). History of choice and choice of history. Religious choice of Kyiv in textbooks of Ukraine. Regional policy: history, political and legal foundations, architecture, urban studies: collection of scientific works. Kyiv-Ternopil: Beskidi, 1, pp. 38-44.

${ }^{10}$ Kroytor A., Yakovlev D., Aleksentseva-Timchenko K. (2019) 'Apostles' of indoctrination: ideological peculiaritie, The Ideology and Politics Journa, №. 2(13), pp. 127-146. Retrieved from: https://ideopol.org/wpcontent/uploads/2019/12/)

${ }^{11}$ Cianciara, A. Zacharuk K. (2018). The Hidden Party Game in Ukraine. In Party Members and Their Importance in Non-EU Countries: A Comparative Analysis, Chapter 9. Retrieved from: https://www.taylorfrancis.com/books/e/9781315201177/chapters/10.4324/ 9781315201177-9

${ }^{12}$ Umland A., Yurchuk Y., Fedor J. (2018) Transmutations and Permutations of the Post-Soviet Ukrainian Radical Right. In book: Journal of Soviet and Post-Soviet Politics and Society Special Section : Issues in the History and Memory of the OUN II. Retrieved from: https://www.researchgate.net/publication/330010576_Special_Section_Issues_in_the_History_a nd_Memory_of_the_OUN_II December 2018

13 Yakovlev, D. (2015). Democracy "On the March": Rethinking the Role of Propaganda and the "Party of Power" under Armed Threat. Proceedings of the Scope: science of politics - International Interdisciplinary Conference of Political Research (Romania, Bucharest 8-9 May, 2015), University of Bucharest, 2015. 
This is the natural way for party policy in the post-Soviet countries. The organizations that have a political purpose appear first. They are initiated by interest groups to be pushed in parliament, and artificially constructed by the power to disperse the opposition electorate. Headquarters are formed, financial conditions for participation in elections are found. And it is only in the course of election campaigns that when deciding a strategy, the elements of ideology are declared, which are not the part of a holistic ideological doctrine, but a component of the technological support of the campaign.

A new trend has appeared: "...the traditional approach to building ideological parties "first ideology, and then - a political organisation" should be changed to the opposite: the first one has to create "living" political organisations and the main function of these organisations will consist in producing a full-fledged "living ideology" in a real-time mode by efforts of the collective intelligence generated as a result of synchronisation of the mental activity of their members. The backbone component in the structure of the "living ideology" has to be the organisational ideal as an integral part of the social ideal" (Plakhtiy, 2015) ${ }^{14}$.

This trend was fully reflected in the 2019 parliamentary elections, which resulted in the newly formed political party "Servant of the People" that gathered $43.16 \%$ of votes (The Central Election Commission, 2019) ${ }^{15}$ and received 251 seats in the Verkhovna Rada of Ukraine (three deputies were subsequently expelled from the faction) ${ }^{16}$.

The aim of our article is to study the election programmes of parliamentary parties. We want to find out, based on the content of the party programmes, an ideological map of the modern Ukrainian parliament and define "white spots" and "hybrids" on it.

${ }^{14}$ Plakhtiy, T., (2015) Prerequisites for Creating Ideological Parties in Ukraine. SSRN. Retrieved from: https://ssrn.com/abstract=2912462 or http://dx.doi.org/10.2139/ssrn.2912462

${ }^{15}$ Elections of People's Deputies of Ukraine Official Website of the Central Election Commission. Retrieved from: https://www.cvk.gov.ua/pls/vnd2019/wp300pt001f01=919.html

${ }^{16}$ Deputies factions and groups of IX convocation, Official web portal Verkhovna Rada Ukrainy. Retrieved from: http://w1.c1.rada.gov.ua/pls/site2/p_fractions 


\section{1. "Seasoned Wolfs": In Search of Paradise Lost}

In today's conditions, the development of the party system of Ukraine is inextricably linked to tectonic transformations of the state and society. It is the process of European integration (or its imitation?), and the informatization of society, which require the adaptation of political institutions and methods of policy implementation to the mediatization of politics and increasing the role and influence of communicative factors (Yakovlev, 2007) ${ }^{17}$. In addition, the aggression of the Russian Federation against Ukraine, the annexation of Crimea, and the war in Donbas have become significant factors in the activities of Ukrainian political parties, which influence their ideological platform. From now on, the issues of defence and the search for ways of resolving the conflict in the East of Ukraine are no longer marginal, but the main ones in the programmes of political parties. The current political situation in the country has led to a new stage in the formation of the ideological spectrum of the Ukrainian party system.

It is worth noting that "uncertainty about political ideologies both in the activities of modern parties and in the minds of society, and the blurring of programmatic foundations of parties in the ideological spectrum along the "right- left" axis, leads to the creation of "quasiparty" structures. The consequence of the blurring of the ideological component of political parties is the structuring of their activities not around a certain political ideology, but a party leader - a person with a high personal rating. That is why election campaigns with the participation of political parties and blocs are becoming personalized" (Krojtor, 2012) ${ }^{18}$.

Modern parties have long ceased to meet the criteria of the classical mass parties because they have become an effective tool in the

${ }^{17}$ Yakovlev, D.V. (2007). Komunikatyvni chynnyky formuvannia demokratychnoi polityky [Communicative factors of democratic policy-making] Contemporary Ukrainian politics. Politicians and political scientists about her, Kyiv, Vol. 9, pp. 167-175.

${ }^{18}$ Krojtor A. V. (2012). Politychna ideologhija jak chynnyk formuvannja partijnoji systemy [Political ideology as a factor in forming the party system] Aktualjni problemy polityky, vol. special issue, pp. 36-44. 
fight for votes. In the course of this struggle, there is a blurring of party ideologies and the actual disappearance of barriers between parties that associate voters solely with a party leader and his image. Successful party brands have been formed in Ukraine. At the same time, there is a simulation of party ideologies, the construction of which takes place around the political position of the party leader, whose rating depends on the competitiveness of a party in the political market.

Party ideology is based on empirical ideological and methodological forms of the subjective perception of political reality. The practical expression of party ideology is contained in the programmatic and statutory documents of political parties. A party ideology aims to express popular political ideas and values in society. In this case, parliamentary elections are a mechanism not only for the rotation of the elite, but also for the selection of basic requirements in the political system, and therefore - determining the dominant political ideology: “... the election result demonstrates the ideological palette in society, the level of influence of individual party ideologies on the process of forming political ideology and public opinion" (Krojtor, 2012) ${ }^{19}$.

The analysis of the legislation of Ukraine in the sphere of regulation of party activities gives grounds to point out that the state avoids the term "ideology" and considers a party as "... a voluntary association of citizens, supporters of a certain national programme of social development, registered under the law, which aims to promote the formation and expression of the political will of citizens, participates in elections and other political events" ${ }^{\prime 20}$.

According to the Law of Ukraine "On Citizens' Associations", a party is defined as an association of citizens, supporters of a certain

${ }^{19}$ Krojtor A. V. (2012). Politychna ideologhija jak chynnyk formuvannja partijnoji systemy [Political ideology as a factor in forming the party system] Aktualjni problemy polityky, vol. special issue, pp. 36-44.

${ }^{20}$ Zakon Ukrajiny "Pro politychni partiji v Ukrajini" [The Law of Ukraine "On Political Parties in Ukraine"] Official web portal Verkhovna Rada Ukrainy. Retrieved from: https://zakon.rada.gov.ua/laws/show/2365-14. 
national programme of social development, whose main aim is to participate in the development of state policy, formation of government bodies, local and regional self-governance and representation in their membership $^{21}$.

However, the practical expression of party ideology is found in the programme documents in the form of the declaration of the purpose and goals of the party, means of achieving this goal, slogans, symbolism, etc. (Krojtor, 2012) ${ }^{22}$.

Therefore, the main document that expresses the ideology of a political party is its programme. According to Article 7 of the Law of Ukraine "On Political Parties", the programme of a political party is a statement of the goals and objectives of this party, as well as the ways to achieve them $^{23}$.

M. Obushny states: "The positive or negative evaluation of the role of parties in the life of modern society is determined mainly by the attitude of a person, social class, class, nation to one or another ideology based on which a political party bases its political and practical activity. Ideology is a fundamental feature in determining the majority of party names, its essence and the principles on which the political platform is developed. That is why ideology is one of the basic characteristics of the activity of a political party" (Obushnyj, Prymush \& Shveda, 2017) ${ }^{24}$.

Y. Schweda defines ideology as a system of views and ideas that expresses a relation to existing reality. Thus, a political ideology should be understood as a system of values, ideas that express political reality

${ }^{21}$ Zakon Ukrajiny "Pro ob'jednannja ghromadjan" [The Law of Ukraine "On Public Association] Official web portal Verkhovna Rada Ukrainy. Retrieved from: https://zakon.rada.gov.ua/ laws/show/2460-12.

${ }^{22}$ Krojtor A. V. (2012). Politychna ideologhija jak chynnyk formuvannja partijnoji systemy [Political ideology as a factor in forming the party system] Aktualjni problemy polityky, vol. special issue, pp. 36-44.

${ }^{23}$ Zakon Ukrajiny "Pro politychni partiji v Ukrajini”" [The Law of Ukraine "On Political Parties in Ukraine"] Official web portal Verkhovna Rada Ukrainy. Retrieved from: https://zakon.rada.gov.ua/laws/show/2365-14.

${ }^{24}$ Obushnyj M. I., Prymush M.V., Shveda Ju.R. (2017) Partologhija [Partology], Kiev, 432 p. 
and attitude to the political process. The central category of political ideology is a political idea (Shveda, 2003) ${ }^{25}$.

It is worth agreeing with $\mathrm{M}$. Obushny, who notes that a political idea should be interpreted as a form of reflection of political reality, as a result of comprehension of the object of cognition - the political process. "In this context, a political idea is a bridge from thought to action, from consciousness to activity. Here, an objective need is reflected in theory through interests, goals, motives of social communities and personalities, it becomes a guide to action. Therefore, the development of new political ideas should be considered as not only an important sphere of spiritual production but also a necessary need to improve the activity of political mechanisms of society. In such circumstances, it is important that the self-fulfilling possibility of a political idea is complemented by appropriate forces and means that would most fully bring it to life" (Obushnyj, Prymush \& Shveda, 2017) ${ }^{26}$.

The party "Petro Poroshenko Bloc-Solidarity" (later "European Solidarity") defines ideology in the programme as follows: "The idea of solidarity is the core principle of our ideology",27. The ideology of the party has a clear nationalist orientation. In particular, it states: "Solidarity is the protection of Ukrainian traditions, the reproduction of values and cultural identity inherited from previous generations. The idea of solidarity is based on our values and beliefs, on which a free solidary society should be built" 28 .

Such provisions of the party programme testify to a commitment to the ideas of national conservatism. For example, the party's programme

${ }^{25}$ Shveda, Ju. R.(2003) Teorija politychnykh partij ta partijnykh system [The theory of political parties and party systems], Lviv: Ivan LNU Publishing Center Franco, 325 p. Retrieved from: http://filelibsnu.at.ua/navchalno-metod/uchebniki/Shveda_Yu-Teoriya_politychnyx_partij_ ta_partijnyx_.pdf.

${ }^{26}$ Obushnyj M. I., Prymush M.V., Shveda Ju.R. (2017) Partologhija [Partology], Kiev, 432 p.

${ }^{27}$ Proghrama politychnoji partiji "Blok Petra Poroshenka 'Solidarnistj' [The program of the political party "Petro Poroshenko Bloc "Solidarity"] Retrieved from: http://solydarnist.org/ wp-content/uploads/2015/12/programa_solidarnist.pdf.

${ }^{28}$ Proghrama politychnoji partiji “Blok Petra Poroshenka 'Solidarnistj' [The program of the political party "Petro Poroshenko Bloc "Solidarity"] Retrieved from: http://solydarnist.org/ wp-content/uploads/2015/12/programa_solidarnist.pdf. 
states that "We have a shared responsibility for preserving and nurturing cultural traditions and passing them on to future generations. Our mission is to preserve historical memory, our identity, our national identity. The state shall create conditions for the development of Ukrainian culture, ensure the status of the Ukrainian language as a single state language, and ensure the development of the culture of national minorities"29.

Among the basic social values that the party has identified as fundamental ones, there is dignity, patriotism, responsibility, democracy, and justice. Defining state policy in the sphere of regulation of the economy, the party advocates minimizing state interference in the economic sphere.

The programme of the party states that "we seek minimal government intervention in the economy while developing opportunities for private enterprise. Giving as much space as possible to the initiative and self-development of citizens in the economy, politics, public life is an important task for the political class of the country" ${ }^{\prime 30}$.

The foreign policy of Ukraine according to the provisions of the party should be aimed at ensuring Euro-Atlantic integration and integration with the EU. The programme of the party identifies the Russian Federation as an aggressor against which foreign policy of the state should be targeted, and effective diplomacy is the method of such fight ${ }^{31}$.

Much attention in the programme of the party is paid to providing by the state its social functions to protect the population and its most vulnerable social groups. The reform of the system of accrual of benefits, pension and medical reform is envisaged. Considering the

\footnotetext{
${ }^{29}$ Proghrama politychnoji partiji "Blok Petra Poroshenka 'Solidarnistj' [The program of the political party "Petro Poroshenko Bloc "Solidarity"] Retrieved from: http://solydarnist.org/ wp-content/uploads/2015/12/programa_solidarnist.pdf.

${ }^{30}$ Proghrama politychnoji partiji "Jevropejsjka Solidarnistj” [European Solidarity Political Party Program] Retrieved from: https://eurosolidarity.org/wp-content/uploads/2019/06/ es_program.pdf.

31 Proghrama politychnoji partiji "Jevropejsjka Solidarnistj” [European Solidarity Political Party Program] Retrieved from: https://eurosolidarity.org/wp-content/uploads/2019/06/ es_program.pdf.
} 
results of the analysis of the programme of "Petro Poroshenko BlocSolidarity" and "European Solidarity" Party, it can be concluded that the programme documents contain the basic ideological principles of the activities of the party, which are expressed in the activities of the parliamentary fraction.

The programme of the party "Fatherland" has a significant social component. It has a pronounced socialist ideological component. In particular, the programme states that the priority of the party is free medicine and education, raising the minimum pensions and salaries. Attention is drawn to the fact that "The minimum pension will be raised to the level of 3094 UAH. No pensioner will receive the pension less than the minimum subsistence level for the retired approved by law" ${ }^{\prime 32}$.

Particular attention is paid to the tariffs and their obligatory reduction by reducing twice the price of gas. The programme promises to raise salaries for educators and healthcare professionals, ensure payments and increase them to young families with children. In particular, the programme states: "Mortgage loans with insurance from the state fund will make it possible to purchase housing without a down payment and collateral, under special risk insurance. The interest rate on such loans will be no more than $3 \%$ per annum. The mortgage loan will be issued for a period of 10 to 30 years" ${ }^{, 33}$.

The priorities of the foreign policy of the All-Ukrainian Union "Fatherland" are the implementation of the Ukraine-European Union Association Agreement and the submission of the NATO Membership Action Plan (MAP) to Ukraine. The programme of the party also emphasizes the need to start a negotiation process on the reintegration of annexed Crimea and Russia-occupied Donbas using the "Budapest +

32 Proghrama politychnoji partiji "Vseukrajinsjke ob'jednannja "Batjkivshhyna" [The program of the political party "All-Ukrainian Union” Homeland"] Retrieved from: https://ba.org.ua/ programm/

33 Proghrama politychnoji partiji "Vseukrajinsjke ob'jednannja "Batjkivshhyna" [The program of the political party "All-Ukrainian Union" Homeland"] Retrieved from: https://ba.org.ua/ programm/ 
formula", involving such states as the United States and the United Kingdom,34.

The elements of the socialist ideology of the party are also traced in the vision of the basic principles of the implementation of agricultural policy in the state by Fatherland. The party has made it clear that its priority in agricultural policy is to continue the moratorium on the sale of land and support small and medium-sized farms and agricultural enterprises. At the same time, it is stated: "Farmers, small and medium-sized farmers who live and work on land will be able to buy their land without auctions at the expense of preferential loans. People who want to sell their land shares will be able to sell them to the state at market value" ${ }^{35}$.

On the other hand, the party is a supporter of the development of small and medium-sized businesses, advocating "macro- and microcrediting of business on European terms". The programme also states that "VAT will be abolished and replaced with a minimum sales tax like in the USA. Instead of a burdensome income tax, a tax on distributed profit will be introduced. And instead of a single social tax, which holds in the shadow of $50 \%$ of salaries, a personalized pension system will be introduced" ${ }^{\prime 36}$.

The party programme does not follow a clear position on important issues of the humanitarian policy of the party, in particular, language, memory policy, religious issues. However, the programmatic position of the party states: "Positive trends in increasing expenditures on cultural financing will be retained and the practice of allocating sufficient funds to finance Ukrainian cinema, books, radio and television content

${ }^{34}$ Proghrama politychnoji partiji "Vseukrajinsjke ob'jednannja "Batjkivshhyna" [The program of the political party "All-Ukrainian Union" Homeland"] Retrieved from: https://ba.org.ua/ programm/

35 Proghrama politychnoji partiji "Vseukrajinsjke ob'jednannja "Batjkivshhyna" [The program of the political party "All-Ukrainian Union" Homeland"] Retrieved from: https://ba.org.ua/ programm/

${ }^{36}$ Proghrama politychnoji partiji "Vseukrajinsjke ob'jednannja "Batjkivshhyna" [The program of the political party "All-Ukrainian Union" Homeland"] Retrieved from: https://ba.org.ua/ programm/ 
will continue. By adopting the law on patronage, we will reduce the burden on the state budget and make the system of financing the culture more flexible",37.

Political party "Opposition Platform - For Life" stands out from the general context of the political parties that won the elections as a result of their views on the domestic and foreign policy of Ukraine. The programme of the party reveals the focus of the party on protecting citizens who profess Soviet values and ideals. The programme makes quite contradictory judgments about the political situation: "For five years, the authorities have systematically violated the rights and restricted the freedoms of millions of Ukrainian citizens. The policy of language bans and harassment, the interference of authorities in the affairs of religious communities have split Ukrainian society, degrading the honour and dignity of people. Opposition platform will end the life of discrimination, xenophobia and radicalism" ${ }^{38}$. Based on this formulation, the party regards the political regime in Ukraine, which emerged from 2014 to 2019, as a "radical regime of xenophobic nature". Such a statement has all the signs of manipulations and is used by the party as a technological technique to mobilise its electorate and reproduce information messages that dominate the information space of the Russian Federation.

In view of the steps that the party is proposing to overcome political tensions in society, it can be considered reactionary. They include "introducing a moratorium on decision-making that splits the country; a policy of reconciliation and consent that will unite the Ukrainians from the West to the East and from the North to the South and "stitch" the country; repealing anti-constitutional, discriminatory laws on language, education, and renaming the church; decommunization,

${ }^{37}$ Proghrama politychnoji partiji "Vseukrajinsjke ob'jednannja "Batjkivshhyna" [The program of the political party “All-Ukrainian Union" Homeland”] Retrieved from: https://ba.org.ua/ programm/

${ }^{38}$ Proghrama politychnoji partiji "Opozycijna platforma - Za zhytttja” [Political party program "Opposition Platform - For Life"] Retrieved from: http://zagittya.com.ua/ua/page/ programma.html. 
lustration and other acts that violate the rights and freedoms of citizens" 39 .

The basis of economic stability is industrialization. This provision makes a dissonance with the views of other parties that the basis of economic development should be the introduction of the latest information technologies ${ }^{40}$.

The programme of the party contains the signs of ideologies of socialism and social democracy. These are the following theses of the programme: "building a social state", "reducing gas tariffs for the population of Ukraine"; "raising the subsistence minimum, the minimum salary, the minimum pension"; "raising payments for a childbirth"; "The main priority is the fight against poverty and social protection of the population"; "We will renew privileges and provide decent state aid to all socially vulnerable categories of the population"41.

In its foreign policy, "Opposition Platform - For Life" focuses entirely on the Russian Federation and advocates: "ensuring active neutrality of Ukraine in the military-political sphere and nonparticipation in any military-political alliances, as provided for in section IX of the Declaration on State Sovereignty of Ukraine; ending the policy of mutual sanctions and renewing mutually beneficial trade and economic ties with Russia and the CIS countries; reviewing of conditions for the participation of Ukraine in the World Trade Organization and the Free Trade Area with the European Union" ${ }^{\text {"42. }}$.

${ }^{39}$ Proghrama politychnoji partiji "Opozycijna platforma - Za zhytttja" [Political party program "Opposition Platform - For Life"] Retrieved from: http://zagittya.com.ua/ua/page/ programma.html.

${ }^{40}$ Proghrama politychnoji partiji "Opozycijna platforma - Za zhytttja” [Political party program "Opposition Platform - For Life"] Retrieved from: http://zagittya.com.ua/ua/page/ programma.html.

${ }^{41}$ Proghrama politychnoji partiji "Opozycijna platforma - Za zhytttja” [Political party program "Opposition Platform - For Life"] Retrieved from: http://zagittya.com.ua/ua/page/ programma.html.

${ }^{42}$ Proghrama politychnoji partiji "Opozycijna platforma - Za zhytttja” [Political party program "Opposition Platform - For Life"] Retrieved from: http://zagittya.com.ua/ua/page/ programma.html. 
Thus, the party does not regard the Russian Federation as an aggressor, and considers resolving the conflict in the Donbas as follows: "ensuring direct negotiations in a Kyiv - Donetsk - Lugansk - Moscow quadrangle; ending the economic blockade of Donbas; granting Donbas autonomous status as an integral part of Ukraine by amending the Constitution and laws of Ukraine; adoption of laws: about amnesty, about elections and free economic zone in Donbas. The implementation of the Plan-Concept of crisis management in the South-East of Ukraine is the way of making peace and returning Donbas to Ukraine and Ukraine to Donbas"43.

The analysis of the "Opposition Platform - For Life" programme gives grounds to claim that the party can be conditionally attributed to centre-left parties, and in the party's views on humanitarian politics - to reactionary ones that focus on the electorate, which is nostalgic for the Soviet past.

\section{Parliamentary neophytes:Is it better to light a candle than curse the darkness?}

One of the important institutions for the implementation of political ideas, their transformation into a strategy of political development of the state, are political parties that, by presenting their ideologies in elections, gain the right to implement them with the support of society.

In such circumstances, the party programme establishes the main ideological tenets of the party and becomes the basis of its ideological activity. However, the analysis of party programmes of political parties of Ukraine, which are represented in the parliament after 2019 elections, shows not only the blurring of party ideologies, the vagueness of ideological provisions and definitions but sometimes also contradictory theses.

For instance, the site of the party "Servant of the People" states that the main values are "transparent activity, openness to the people, the responsibility to the country, and teamwork. Party members should

${ }^{43}$ Proghrama politychnoji partiji "Opozycijna platforma - Za zhytttja” [Political party program "Opposition Platform - For Life"] Retrieved from: http://zagittya.com.ua/ua/page/ programma.html. 
always be honest and remain people!" and the aim of the party is to "make the Ukrainians equal before the law, the people's deputies responsible and punish bribe-takers. To give the economy a chance to develop, put the system in order, build a humanitarian policy that unites Ukraine" ${ }^{\text {"44. }}$.

The preamble to the programme of the party does not define the ideological foundations of the "Servant of the People" activities and states that the party "is going to early parliamentary elections to bring decent people to the Verkhovna Rada of Ukraine who will serve Ukraine and their constituents. We will embody President Zelensky's course in specific bills and political decisions, form a professional government that will be trusted by the people of Ukraine, and together introduce drastic changes that will help us make Ukraine a free, independent, successful Country of Dreams" $" 45$.

Overall, the programme document contains provisions that characterize both liberal and social-democratic ideologies. So the party stands for deregulation, demonopolization of the economy and at the same time expansion of the social welfare of citizens.

Regarding the reform of state authorities, the party insists on:

- Abolition of parliamentary immunity;

- Introduction of an imperative mandate;

- Creation of a mechanism of popular veto on the just adopted laws.

As for the last point, the programme does not specify how they can be implemented in Ukraine. It should be noted that the legislative process that took place in the parliament in the so-called "turbo mode" after the beginning of the Verkhovna Rada's work showed that this proposal was a populist promise, which lost its relevance immediately after the formation of the majority;

- Introduction of the mechanism of influence of citizens on the decisions of the government through referendums. This situation also

${ }^{44}$ Proghrama politychnoji partiji "Slugha narodu" [Servant of the People's Political Party Program] Retrieved from: https://sluga-narodu.com/

${ }^{45}$ Proghrama politychnoji partiji "Slugha narodu" [Servant of the People's Political Party Program] Retrieved from: https://sluga-narodu.com/ 
raises a number of questions. The referendum, as a form of direct democracy, is envisaged by the Constitution of Ukraine. However, the party does not determine what mechanisms will ensure the implementation of this form of democracy;

- Restitution of officials' liability for illegal enrichment. It sounds more like the slogan of all political parties that participated in the 2019 election campaign.

In addition, the political party "Servant of the people" is in favour of introducing a proportional electoral system with open lists and electronic voting. The party considers the introduction of mechanisms that would ensure the independence of journalists from media owners an important task in the field of media activity. At the same time, there are no such mechanisms in the programme of the party.

The main measures to combat corruption, which is a priority task for all parties, "Servant of the People" in the programme of the party indicates the following: "We will implement the maximum possible number of public services online; clean up and restart the prosecutor's office; ensure real independence of anti-corruption bodies; restart ineffective or compromised bodies; introduce mandatory confiscation of corrupt property; introduce a system of financial compensation for citizens for detecting corruption; deprive the Security Service of Ukraine, the Procurator-General and the National Police of non-peculiar business harassment functions" ${ }^{\prime 46}$. These provisions are not new in the Ukrainian political space. However, the party does not reflect the specific mechanisms of their implementation in its programme. It is interesting to note the provision on "business harassment" by the Security Service of Ukraine, the Procurator-General and the National Police, as it does not specify in a sufficiently broad formulation which functions of these law enforcement agencies put pressure on entrepreneurship.

In the field of security and defence, the "Servant of the People" Party, using, as in the previous sections of the programme, the verbs of

${ }^{46}$ Proghrama politychnoji partiji "Slugha narodu" [Servant of the People's Political Party Program] Retrieved from: https://sluga-narodu.com/ 
present and future tenses, promises: "We will provide legislative support to the President's initiatives aimed at restoring the territorial integrity and state sovereignty of Ukraine; establish expenses on defence at the rate of at least 5\% of GDP; renew the reformation the Armed Forces by NATO standards; stop the outflow of valuable personnel from the army; introduce a system of training and retraining of soldiers and officers; introduce the harshest penalties for corruption and theft in the Armed Forces and the Ministry of Defence of Ukraine; decentralize and demonopolise defence public procurement" ${ }^{\text {"47 }}$.

These provisions have manipulative features, in particular regarding the resumption of reforming of the Armed Forces of Ukraine, since their reform process began in 2014 and the budget of the Armed Forces has been steadily increasing since 2015 .

In the field of foreign policy, "Servant of the People" acts as a proEuropean party supporting the Euro-Atlantic integration of Ukraine. It should be noted that the programme does not define the role of the Russian Federation in the annexation of Crimea, the conflict in the Donbas. The party does not express its attitude to these processes.

In the sphere of culture and national politics, the party intends to implement a humanitarian policy that will promote the cultural, civic and spiritual unification of Ukrainian citizens. At the same time, some statements made by party leaders and some of its members contradict the provisions of the programme of the party, including provisions on linguistic, security and foreign policy.

Furthermore, party leaders cannot determine the party's ideological affiliation. In particular, the leader of the "Servant of the People" at the party congress stated: "Our ideology is libertarian. Will it change? It will be refined since libertarian ideas are not supported by all party members. That is, some compromise should be found between liberal and socialist views" ${ }^{\prime 4}$.

${ }^{47}$ Proghrama politychnoji partiji "Slugha narodu" [Servant of the People's Political Party Program] Retrieved from: https://sluga-narodu.com/

${ }^{48}$ Biljshe ne libertarianci: Kornijenko zajavyv pro zminu ideologhiji "Slughy narodu" [No longer libertarians: Kornienko declared change of ideology of "Servant of the people"] 
The party leader recognizes that his organization is not the unity of people who share common values and ideals. In particular, O. Kornienko pointed out that "We have human-centrism. Now, looking at our decisions, we are moving towards democracy, in the direction of increasing opportunities for people. However, there are also conservative points connected with the fact that it is difficult to create liberalism in Ukraine at once" 49 .

Therefore, one can expect the ideological drift of the party in the future, most likely towards socialism. These tendencies, associated with changing party ideology, are normal, given that most parties are universal and try to reach as much of the electorate as possible. Populism is becoming a feature not only of national party projects but of political parties in a global context.

It is worth noting the conscious appeal to utopias: “... together we will introduce drastic changes that will help us make Ukraine a free, independent, successful Country of Dreams". The purpose of the party is to transform Ukraine into a "utopian" "Country of Dreams". Thus, the party gains the support not of sympathizers of a particular ideology, but of the politically indeterminate masses who believe in political utopias.

In this sense, the programme of the "Voice" party is quite similar to the programme of "Servants of the People". It is also characterized by emotionality. However, the programme provisions broadly outline the basic principles, goals and means of achieving the core objectives of the party. The programme also lacks a clear definition of the party's ideological affiliation. Some provisions point to both socialist and liberal ideas. In particular, the party aims to fight the monopolization of the economy, promote the development of an entrepreneurial activity, reduce

Dzerkalo tyzhnja. Retrieved from: https://dt.ua/POLITICS/bilshe-ne-libertarianci-korniyenkozayaviv-pro-zminu-ideologiyi-slugi-narodu-329152_.html.

${ }^{49}$ Biljshe ne libertarianci: Kornijenko zajavyv pro zminu ideologhiji "Slughy narodu" [No longer libertarians: Kornienko declared change of ideology of "Servant of the people"] Dzerkalo tyzhnja. Retrieved from: https://dt.ua/POLITICS/bilshe-ne-libertarianci-korniyenkozayaviv-pro-zminu-ideologiyi-slugi-narodu-329152_.html. 
the regulatory impact of the state on the economy and build an effective social security system.

The clear ideological affiliation of the party is difficult to determine. This is a hybrid ideology. The programme of the party states that "Voice" goes to politics to return a person to the centre of the state, stop the division into left and right, nationalists and liberals, and unite around people and their indestructible dignity. The citizen Ukraine is above all. The state is in the palm of a person, but not a person in the fist of the state".

Unlike "Servant of the People", the party "Voice" does not aim at the fictional "Country of Dreams". However, the task of its activity is that "We will get rid of what now does not allow Ukraine to spread its wings and move forward. We are realizing the potential of Ukraine that has been talked about for so many years. We are creating strong and innovative Ukraine, a true Eastern European tiger" ${ }^{\text {"50. }}$

The programme of the party focuses on justice as a social value and a person whose interests are intended to serve the state. Regarding the cultural aspect of social life, the programme of "Voice" states: "In Ukraine, new, modern cultural traditions should be established and finally unite the Ukrainian nation, cementing its identity. We will contribute to the enrichment of national culture with various achievements of global culture. Preservation of authenticity should not interfere with the modernization of culture" ${ }^{, 51}$. This programme statement proves that regarding national matters the party is quite moderate and centrist. Language policy has not been given much attention in the programme of the party. However, this is compensated by a large number of statements made by the party leader S. Vakarchuk in support of the Ukrainian language and its status in society.

The mechanisms for clearing and reforming the judicial system are presented in more details by "Voice" than by "Servant of the People". In

${ }^{50}$ Proghrama politychnoji partiji "Gholos" [The Political Party's "Voice" Program] Retrieved from: https://goloszmin.org/storage/app/media/files/Program.pdf.

${ }^{51}$ Proghrama politychnoji partiji "Gholos" [The Political Party's "Voice" Program] Retrieved from: https://goloszmin.org/storage/app/media/files/Program.pdf. 
particular, it is stated in the programme of "Voice" that "to run the changes, you need to restart the system of selecting and supervising judges. The system cannot clean itself. That is why we need to recruit honest and competent judges into the key bodies (the High Qualifications Commission of Judges and the High Council of Justice) and public experts with an impeccable reputation. We will be assisted by international experts, who have already managed to prevent an unprecedented number of unworthy judges in the Anti-Corruption Court..."52.

The party in the programmatic provisions is quite positive about the system of anti-corruption bodies established in the state. However, it notes that "at present, these structures are not working smoothly, and the management of SAPO and NABU are not doing their job and playing along with corruptors. We know how to rectify an effective anticorruption system that will put an end to the impunity of large-scale corruption" (10). To overcome this problem, the party promises to implement a number of measures that are quite broadly outlined in the programme.

In economic policy, the party pays close attention to the IT sector. Thus, the programme contains provisions on the need to adopt the "Digital Freedom Act",

The party "Voice" was not an exception among the parties that announced their intentions to fight the oligarchy. In particular, the party's programme states: "A dozen masters of life" have no right to control national policy and information field (four oligarchic groups control about $75 \%$ of the country's television market), place their people in key positions in the state and use captured state structures for promotion of interests of their business. We will strike simultaneously at all sources of influence of the oligarchs: economic monopolies, media control and politics. To do this we will apply antitrust legislation, appoint

${ }^{52}$ Proghrama politychnoji partiji "Gholos" [The Political Party's "Voice" Program] Retrieved from: https://goloszmin.org/storage/app/media/files/Program.pdf.

${ }^{53}$ Proghrama politychnoji partiji "Gholos" [The Political Party's "Voice" Program] Retrieved from: https://goloszmin.org/storage/app/media/files/Program.pdf. 
professionals who are ready to fight the oligarchs into key state regulators and introduce stringent requirements for the editorial independence of the media. We will also harness the potential of modern information technology to effectively collect and analyze information about the members of oligarchic groups" ${ }^{, 54}$.

Concerning the electoral reform of the electoral system, the positions of the party "Voice" are identical to the positions in the programme of "Servant of the People".

They promise the following: "We will introduce a long-overdue system of open list elections; the majority system must be abolished. This will open the way to politics for decent and professional people, not a limited number of rich people who can buy a position in the list. We support the abolition of immunity for members of parliament, except in cases where they directly fulfil their functions as legislators and representatives of the people. We are in favour of reducing the number of members of parliament" ${ }^{, 55}$.

The programme of the party also contains a statement similar to the programme of "Servant of the People" about the need to involve citizens of the state in the process of political decision-making. In particular, the promise of transparency of power is given.

It is determined: "We will open the Parliament; we will increase the participation of citizens in decision-making through the tools of edemocracy. Every citizen will be able to vote on their smartphones, join the distribution of state or local budgets, and evaluate the work of politicians and officials". It should be noted that these statements are populist.

In foreign policy, similar to "Servant of the People", "Voice" is focused on the integration with the EU and NATO. But unlike "Servant of the People", the party "Voice" clearly defines its position regarding the aggressor country.

${ }^{54}$ Proghrama politychnoji partiji "Gholos" [The Political Party's "Voice" Program] Retrieved from: https://goloszmin.org/storage/app/media/files/Program.pdf.

${ }^{55}$ Proghrama politychnoji partiji "Gholos" [The Political Party's "Voice" Program] Retrieved from: https://goloszmin.org/storage/app/media/files/Program.pdf. 
The programme states: "We will not surrender positions on the diplomatic front: pressure and isolation of Russia on the world stage must intensify, and Ukraine will return to the European civilizational and security space ... We will use the whole diplomatic arsenal to stop the fire as soon as possible and stabilize the situation in Donbas, and subsequently to restore the territorial integrity of Ukraine. Crimea is Ukraine and it will not become a bargaining chip on any agreements" $"$.

The programme of the party clearly states its position on the role of the Russian Federation as an aggressor and occupier in the conflict in eastern Ukraine.

It is stated: "Our ultimate goal is to return our territories and win the war for the right of Ukraine to self-determination. We strongly oppose any plans that involve the representatives of the terrorist groups in government or local authorities led by the Russian Federation. Peace, bought at the cost of the partial loss of sovereignty in favour of the Russian aggressor, will never be permanent; it can lead to an even greater war in Ukraine. We will do everything necessary for the bloodless deoccupation of the occupied territories and the safe reintegration of the people whom Russia has taken hostage, their return to a normal, dignified life. We need to stop the murder of Ukrainian citizens. It is a crime that Russia is responsible for".

In his speech at the party congress, S. Vakarchuk described the ideological foundations of the party: "The interests of Ukrainian citizens are above all, the existential choice of Ukraine is Europe, one law for all, a free economy without oligarchs, a power that is accountable to the citizens of Ukraine. These are the ideas. We will reveal the details of these ideas later; you will see them in our programme" 57 .

${ }^{56}$ Proghrama politychnoji partiji "Gholos" [The Political Party's "Voice" Program] Retrieved from: https://goloszmin.org/storage/app/media/files/Program.pdf.

${ }^{57}$ Vakarchuk ozvuchyv ideologhiju partiji "Gholos" [Vakarchuk voiced the ideology of the Voice Party] Rubryka. Retrieved from: https://rubryka.com/2019/05/16/vakarchukozvuchyv-ideologiyu-partiyi-golos/ 


\section{CONCLUSIONS}

The study of the programmatic provisions of the political parties of Ukraine, which overcame the barrier as a result of the parliamentary elections, allows us to draw the following conclusions.

First, in Ukraine, the ideological factor is not decisive for winning the parliamentary electoral campaign. The political parties that had positioned themselves as new projects, such as "Servant of the People" and "Voice", won. They used the non-political popularity and mass recognition of the leader (V. Zelensky, S. Vakarchuk) rather than ideology for electoral support.

Second, such political parties as "European Solidarity", "Fatherland", and "Opposition Platform - For Life" have an ideological niche, positioning themselves on the Ukrainian and European ideological map (through participation in the activities of the fractions of the European Parliament). Will this help them gain popularity in the next elections and expand their electoral field? It depends on the actions of the contemporary "party of power". An important indicator here will be the process of resolving the armed conflict in Donbas;

Third, the newly formed political parties remain the leader parties whose rating engines are their leaders. So far, they have not paid enough attention to positioning in the ideological space, which can have negative effects on their rating. This is a threat especially for the party "Servant of the People" whose rating depends on the personal popularity of V. Zelensky.

Fourth, most "left-centrist-right-wing" parties in their programmes position themselves as centrist parties of liberal or social-democratic orientation. However, insufficient attention is paid to social policy and social protection issues. These issues are presented as a separate section only in the programme of "Opposition Platform - For Life".

Fifth, in relation to humanitarian policy, according to the programmes of "European Solidarity", "Fatherland", and "Voice" parties, they position themselves as national democratic parties. "Opposition Platform - For Life" can be attributed to the parties that profess a Soviet system of ideological values and a Russian-oriented information space. 
Sixth, all political parties that won the support of the electorate, except "Opposition Platform - For Life", have a pro-European orientation, declaring the need to continue the course for European and Euro-Atlantic integration.

Seventh, a characteristic feature of such parties as "Voice" and "Servant of the People" is the virtualisation of their activities and the lack of an extensive organizational regional structure.

The tendency of modern political parties is "the high level of ideological mobility and receptiveness, the ability to integrate individual postulates of competing political ideologies into the programme of a party" (Krojtor, 2012) ${ }^{58}$.

Parliamentary parties balance between (1) the "Ukrainian electoral standard", which was formed in times of independence and provides formal mentioning of raising salaries and pensions and reducing tariffs, (2) open populism and manipulation to gain the support of the most socially disadvantaged groups and (3) a comprehensive ideological identification following existing ideological matrices and world trends. The results of our study show that the third ones are in absolute minority, and the danger of populism will increase in proportion to the decline in the level of well-being of citizens.

\section{SUMMARY}

The article is devoted to the study of political ideology as a factor of formation of the party system of Ukraine based on the analysis of programmes of political parties of Ukraine. The article analyses the programmes of such political parties: "Servant of the People", "Voice", "European Solidarity", "All-Ukrainian Union Fatherland”, "Opposition Platform - For Life". In the process of parliamentary elections in 2019, ideology was not a determining factor. The "Servant of the People" party, which won by a wide margin and received the majority of votes in parliament, pays little attention to ideology. Internal party discussions

${ }^{58}$ Krojtor A. V. (2012) Politychna ideologhija jak chynnyk formuvannja partijnoji systemy [Political ideology as a factor in forming the party system] Aktualjni problemy polityky, vol. special issue, pp. 36-44. 
regarding ideological doctrine have continued so far. On the contrary, parliamentary old-timers, who have a relatively comprehensive ideological doctrine, received minimal electoral support. This is an alarming signal that will lead to a decrease in attention to ideologies in the next elections.

The features of party programmes and their ideological components are determined. It is proved that political parties of Ukraine are parties of universal type with blurred ideological orientations.

\section{REFERENCES}

1. Barkouski, P. (2018). Contemporary post-ideologies: "hybrid ideologies", or "new mythologies" as a factor of constituting of postmodern social field, The Ideology and Politics Journal, № 3(11), pp. 13-55. Retrieved from: https://ideopol.org/wp-content/uploads/ 2018/12/___Eng_2018\%203.\%204.\%20Barkouski\%20.pdf (accessed 17 February 2020)

2. Barrett, R. (2018). Ukraine at the Crossroad in PostCommunist Europe : Policymaking and the Role of Foreign Actors. Dissertations, 259 p. Retrieved from: https://irl.umsl.edu/dissertation/725 (accessed 17 February 2020)

3. Biljshe ne libertarianci: Kornijenko zajavyv pro zminu ideologhiji "Slughy narodu" [No longer libertarians: Kornienko declared change of ideology of "Servant of the people"] Dzerkalo tyzhnja. Retrieved from: https://dt.ua/POLITICS/bilshe-ne-libertariancikorniyenko-zayaviv-pro-zminu-ideologiyi-slugi-narodu-329152_html (accessed 17 February 2020)

4. Cianciara, A. Zacharuk K. (2018). The Hidden Party Game in Ukraine. In Party Members and Their Importance in Non-EU Countries: A Comparative Analysis, Chapter 9. Retrieved from: https://www.taylorfrancis.com/books/e/9781315201177/chapters/ 10.4324 / $9781315201177-9$ (accessed 17 February 2020)

5. Guttke, M., Küchler, F., Shvaika, O. (2012). Ideological Foundations of Educational Reforms in Ukraine, The Ideology and Politics Journa, № 2, pp .4-13. Retrieved from: https://ideopol.org/ 
17 February 2020)

6. Deputies factions and groups of IX convocation, Official web portal Verkhovna Rada Ukrainy. Retrieved from: http://w1.c1.rada.gov.ua/ pls/site2/p_fractions (accessed 17 February 2020)

7. Elections of People's Deputies of Ukraine Official, Website of the Central Election Commission. Retrieved from: https://www.cvk.gov.ua/ pls/vnd2019/wp300pt001f01=919.html (accessed 17 February 2020)

8. Krojtor A. V. (2012) Politychna ideologhija jak chynnyk formuvannja partijnoji systemy [Political ideology as a factor in forming the party system] Aktualjni problemy polityky, vol. special issue, pp. 36-44.

9. Kroytor A., Yakovlev D., Aleksentseva-Timchenko K. (2019). "Apostles" of indoctrination: ideological peculiaritie, The Ideology and Politics Journa, №. 2(13), pp. 127-146. Retrieved from: https://ideopol.org/ wpcontent/uploads/2019/12/ (accessed 17 February 2020)

10. Minakov, M. (2012). Ideological Innovations in the PostSoviet Countries. Editorial introduction. The Ideology and Politics Journal, № 1, pp. 2-4. Retrieved from https://ideopol.org/wpcontent/uploads/ 2014/03/1_ENG__Minakov.pdf (accessed 17 February 2020)

11. Mochulska, M. (2017).The legal status of political parties in Ukraine: peculiarities and improvement. Zeszyty naukowe, № 4. Retrieved from http://iusetadministratio.eu/wp-content/Zeszyty_naukowe/ 2017/4_2017/4_2017_1_Mochulska.pdf (accessed 17 February 2020)

12. Obushnyj M. I., Prymush M.V., Shveda Ju.R. (2017) Partologhija [Partology], Kiev, 432 p.

13. Plakhtiy, T., (2015). Prerequisites for Creating Ideological Parties in Ukraine. SSRN. Retrieved from: https://ssrn.com/abstract= 2912462 or http://dx.doi.org/10.2139/ssrn.2912462

(accessed 17 February 2020)

14. Proghrama politychnoji partiji "Blok Petra Poroshenka "Solidarnistj" [The program of the political party "Petro Poroshenko 
Bloc "Solidarity"] Retrieved from: http://solydarnist.org/wp-content/ uploads/2015/12/programa_solidarnist.pdf. (accessed 17 February 2020)

15. Proghrama politychnoji partiji "Gholos" [The Political Party's "Voice" Program] Retrieved from: https:/goloszmin.org/storage/app/ media/files/Program.pdf. (accessed 17 February 2020)

16. Proghrama politychnoji partiji "Jevropejsjka Solidarnistj" [European Solidarity Political Party Program] Retrieved from: https://eurosolidarity.org/wp-content/uploads/2019/06/es_program.pdf. (accessed 17 February 2020)

17. Proghrama politychnoji partiji “Opozycijna platforma - Za zhytttja" [Political party program "Opposition Platform - For Life"] Retrieved from: http://zagittya.com.ua/ua/page/programma.html. (accessed 17 February 2020)

18. Proghrama politychnoji partiji "Slugha narodu" [Servant of the People's Political Party Program] Retrieved from: https:// sluga-narodu.com/ (accessed 17 February 2020)

19. Proghrama politychnoji partiji "Vseukrajinsjke ob'jednannja "Batjkivshhyna" [The program of the political party "All-Ukrainian Union" Homeland"] Retrieved from: https://ba.org.ua/programm/. (accessed 17 February 2020)

20. Shveda, Ju. R. (2003). Teorija politychnykh partij ta partijnykh system [The theory of political parties and party systems], Lviv: Ivan LNU Publishing Center Franco, 325 p. Retrieved from: http://filelibsnu.at.ua/navchalno-metod/uchebniki/Shveda_Yu-Teoriya_ politychnyx_partij_ta_partijnyx_.pdf. (accessed 17 February 2020)

21. Umland A., Yurchuk Y., Fedor J. (2018). Transmutations and Permutations of the Post-Soviet Ukrainian Radical Right. In book: Journal of Soviet and Post-Soviet Politics and Society Special Section : Issues in the History and Memory of the OUN II. Retrieved from: https://www.researchgate.net/publication/330010576_Special_Section_Is sues_in_the_History_and_Memory_of_the_OUN_II December 2018 (accessed 17 February 2020)

22. Vakarchuk ozvuchyv ideologhiju partiji "Gholos" [Vakarchuk voiced the ideology of the Voice Party] Rubryka. Retrieved 
from: https://rubryka.com/2019/05/16/vakarchuk-ozvuchyv-ideologiyupartiyi-golos/ (accessed 17 February 2020)

23. Whitmore, S. (2014). Political party development in Ukraine. GSDRC Helpdesk Research, Birmingham, UK, 2014, Report 1146, pp. 1-13. Retrieved from http://www.gsdrc.org/docs/open/hdq1146.pdf (accessed 17 February 2020)

24. Yakovlev, D. (2015). Democracy "On the March": Rethinking the Role of Propaganda and the "Party of Power" under Armed Threat. Proceedings of the Scope: science of politics International Interdisciplinary Conference of Political Research (Romania, Bucharest 8-9 May, 2015), University of Bucharest, 2015.

25. Yakovlev, D., Kroytor, A.. (2018). History of choice and choice of history. Religious choice of Kyiv in textbooks of Ukraine. Regional policy: history, political and legal foundations, architecture, urban studies: collection of scientific works. Kyiv-Ternopil: Beskidi, 1, pp. 38-44.

26. Yakovlev, D.V. (2007). Komunikatyvni chynnyky formuvannia demokratychnoi polityky [Communicative factors of democratic policy-making] Contemporary Ukrainian politics. Politicians and political scientists about her, Kyiv, Vol. 9, pp. 167-175.

27. Yenin, M. (2018). Ideological forms and value modifications of patriotism of Ukrainian youth (based on analysis of moderated group discussions), The Ideology and Politics Journal, № 2(10). Retrieved from https://ideopol.org/wp-content/uploads/2019/01/ 2.\%203.\% 202018.\%20ENG. \% 20Yenin.pdf (accessed 17 February 2020)

28. Zakon Ukrajiny 'Pro ob'jednannja ghromadjan' [The Law of Ukraine "On Public Association"] Official web portal Verkhovna Rada Ukrainy. Retrieved from: https://zakon.rada.gov.ua/laws/show/2460-12. (accessed 17 February 2020)

29. Zakon Ukrajiny "Pro politychni partiji v Ukrajini" [The Law of Ukraine "On Political Parties in Ukraine"] Official web portal Verkhovna Rada Ukrainy. Retrieved from: https://zakon.rada.gov.ua/ laws/show/2365-14. (accessed 17 February 2020) 


\section{Information about the authors:}

Yakovlev D. V.,

Prof. dr hab.,

Dean of the Faculty of Psychology,

Political Science and Sociology,

National University Odessa Law Academy

23, Fontanska str., Odessa, 65009, Ukraine

ORCID ID: orcid.org/0000-0003-2828-4669

Kroytor A. V.,

$\mathrm{PhD}$, Department of Political Science, National University Odessa Law Academy 23, Fontanska str., Odessa, 65009, Ukraine ORCID ID: orcid.org/0000-0003-4652-7441 